Marius Crous

Marius Crous is a language practitioner at the Parliament of South Africa. His debut collection of poetry Brief uit die kolonies (Protea Book House, 2003) received the RAU award. He holds postgraduate degrees in Literary

Theory and English as well as a doctorate in Afrikaans and Dutch.

E-mail:mcrous@parliament.gov.za

\section{"Note on sex for the aged widower": On André Brink's The Rights of Desire}

\title{
"Note on sex for the aged widower": On André Brink's The Rights of Desire
}

This article examines the representation of masculinity in André Brink's novel, The Rights of Desire. Following a remark in Roger Boylan's review of the novel in the Boston Review; this analysis concentrates on Brink's depiction of Afrikaner masculinity and the idea that the character Ruben Olivier represents Brink's conception of the contemporary Afrikaner male, in particular the older Afrikaner male. This is an attempt at determining the validity of Robert Morrell's thesis on masculinity, namely that it is about "men making and remaking masculinity, about challenging hegemonic masculinity and reconstituting it." The question is whether Brink's portrayal of Afrikaner masculinity confronts the hegemonic and patriarchal power structures associated with Afrikaner men, and whether it provides the reader with a new perspective on Afrikaner masculinity. This article investigates Brink's representation of firstly, the ways Afrikaner men relate to other men, and secondly, the depiction of Afrikaner men in relation to their social class and to women. Key words: masculinity, André Brink, Afrikaner masculinity, hegemonic masculinity.

In his review of André Brink's novel, The Rights of Desire, Roger Boylan (2001) points out that the main female character in the novel, Tessa Butler, is "an embodiment of beautiful, dangerous, modern South Africa" whereas Ruben, the protagonist, "symbolizes the resilience of Afrikaners who helped mould the country". He concludes: "Like his Boer forebears, [Ruben has] learned to live alone. And then comes Tessa to awaken his old man's desire, which feels the same as a young man's." In the new South Africa, of which this novel "stands as both narrative about and metaphor for" (Schroeder 2001), the position of white males, and in particular the Afrikaner male, has changed essentially because of the change in social status and their loss of political power. In this regard, Andries Visagie (2001: 139) points out that the "death knell" for white male supremacy became a reality in the new South Africa, resulting in "a new definition of Afrikaner masculinity" that had to take shape "to compensate for the severing of the bond between white masculinity and political power." ${ }^{1}$ Sandra Swart (2001: 77) is of the opinion that in the new South Africa, Afrikaner masculinity has moved "from a hegemonic, indeed an exemplary identity to a socially marginalised, and in many sectors, an actively dishonoured identity." Bearing this in mind, the emphasis in this article $^{2}$ is on the portrayal of Afrikaner masculinity in Brink's The Rights of Desire, as an 
attempt at determining the validity of Robert Morrell's (2001: 270) thesis that masculinity is about "men making and remaking masculinity, about challenging hegemonic masculinity and reconstituting it." In his portrayal of Afrikaner masculinity, does Brink confront the hegemonic and patriarchal power structures associated with Afrikaner men or does he provide the reader with a new perspective on Afrikaner masculinity? In Brink's representation (1) how do Afrikaner men relate to other men and (2) how does he depict them in relation to their social class and to women? ${ }^{3}$

The following propositions form the basis of this analysis of Brink's presentation of Afrikaner masculinity that the character

- Willem Mostert, the master and lover of the slave woman, Antje of Bengal, serves as Brink's exemplar of traditional Afrikaner masculinity;

- Ruben Olivier represents Brink's conception of the contemporary Afrikaner male, in particular the older Afrikaner male, in facets of his life such as (a) his relationship with his farmer-father, (b) his role as husband and father and (c) his relationship with the much younger Tessa, whose lover and/or protector he desires to be. ${ }^{4}$

Masculinities in South Africa have "been forged in the heat of apartheid and the struggle against the apartheid state" and white men in particular construct their notion of masculinities "in relation to the ways that they saw women and black men (or men of colour generally)" (Epstein 1998: 49). In "the new South Africa" after 1994, we have a "post-struggle masculinity", which, according to Thokozani Xaba (2001: 109 ) is characterised by "respect for law and order, respect for public order, resumption of paying for services, respect for state institutions and co-operation with the police to fight crime." The defiance against authority associated with the struggle had to be replaced and the so-called "configurations of masculinity forged in one historical moment" (Xaba 2001: 119) had become obsolete.

In the aftermath of apartheid, white men, and in particular Afrikaner men associated with the National Party state apparatus have lost their privileged positions. In the new dispensation the older members of this group experienced a distinct loss of political power (but not necessarily a loss of economic power). The younger generation of white males tended to feel threatened by affirmative action and gender equality (Du Pisani 2001: 171). Swart (2001: 77) captures the essence of this trend as follows: "[Being a] white male meant being kept from poverty, with jobs in the traditional Afrikaner preserves like the mines, the railways, the police and the civil service being handed down 'from father to son'. Now fathers are retrenched and the sons face competition from blacks in the work place."

In the modern patriarchy of South African society, where African men have acquired political power, African women are faced with new difficulties, in particular assumptions relating to the maleness of African power. Some social scientists estimate 
that rape is on the increase and this could be an effect of the mindset that was predominant during the struggle years, namely that women were considered to be fair game (Xaba 2001: 116). Deborah Posel (2005: 21) argues, however, that before the mid-1990s sexual violence "languished on the margins of public debate and political engagement" and that it only recently entered the public domain, particularly following a brutal baby rape in December 2001. The subsequent public anger focused on the sexual behaviour of South African men and social society authorities called for a moral regeneration campaign.

In contemporary South Africa the predominantly white colonial notion of manliness associated with "Anglo-Saxon virtues" (Midgeley 1998: 196) is now replaced with "new hegemonic reifications of race, nation, citizenship and sexuality" (Spurlin 1999: 232) aimed at establishing a South African identity. It is especially important to bear in mind, however, that to imply that all South African men are chauvinistic, misogynistic and homophobic is to adopt a reprehensibly essentialist perspective, as Morrell (2001: 33) points out, there is "no one typical South African man".

In the opening paragraph of the novel reference is made to Willem Mostert, Antje of Bengal's "violent lover and master" (3), which prepares the reader for what will ensue in the novel. Willem was the first owner of the house in which Ruben now lives and one could interpret the house as a symbol or microcosm of South African society. Compare in this respect Heilna du Plooy's remarks "His house encapsulates the story of his life and his life evolves within the space of his house. His house carries the memories of the history of the people of the land, the land in which he has to survive; but both the past and the present also occur within this house" (du Plooy 2002: 50; my translation). ${ }^{5}$

By focusing on events in the house from the colonial times to the present, one could necessarily identify a historical lineage that stretches from the time of Willem to the present times of Ruben's life. Mostert was "the first owner of [the] house" (40) and Brink presents him as the precursor of the Afrikaner men subsequently living in this microcosm. Willem Mostert is presented as a pillar of society at the Cape. As a member of the hegemonic class, he was in the position to abuse his slaves as it pleased him. Willem Mostert's obsession with Antje, a girl "barely nubile" (40), and his subsequent sexual abuse of her, provides a clear example of the "unseen and permissible rape of women of colour by white men" (Samuelson 2002: 91) that formed the essence of the institution of slavery. The description of their relationship also makes several interesting comments on eighteenth century Cape society. Willem arrived, "practically penniless" (41) at the Cape, but managed to seduce Susara Uytenbogaert, an affluent widow (41) and marry her for her money. The result is that he becomes a rich and important man in society and a prominent member of the so-called "Cape elite" (47).

As an affluent and influential man he does not want to jeopardize his position and be disgraced in the eyes of the community (44). To avoid divorce proceedings he gives 
"a startlingly different account" of what has really happened between him and his wife. He also gives "a hefty contribution to the church coffers" (44) which not only suggests corrupt practices on the side of the then socially very powerful church, but also shows how interlinked the different power structures are, which work together in informal co-operation. That is also evident later on during the trial of Antje of Bengal when she is hauled before the court "on the charge of murder", whereas Willem is never "indicted, never even summoned as a witness" (47). An imaginary "perceptive historian" cited in the text explains that the master-slave class distinction accounts for the Cape political authorities' lack of action against Willem Mostert (47).

The eighteenth-century colonial Afrikaner is aware of his dominant position in society. Robert Ross (1993: 156) shows that at the Cape of the time, "the Dutch had used the law to maintain distinctions of status between master and slave" and since there was no separation of power, and that was concentrated in very few hands. The Afrikaner male's dominant position in society will only be completely altered in the lifetime of his scion, Ruben Olivier, when he has to deal with issues such as affirmative action and early retirement - to mention but two examples.

The depiction of Afrikaner male sexuality in this novel suggests that the men were manipulative and saw women merely as a means to an end: be it financially as in the case of Susara, or sexually as in the case of Antje. Willem simply used Susara to obtain a position of financial security, because as soon as that is established, he leaves "the solid, canopied conjugal bed at night" (41) to satisfy his sexual desire for the Other. The narrator creates the impression that there was mutual passion and consent between Willem and Antje, but because of the power imbalance and in view of Antje's age, that would have been impossible. Willem is also not representative of what Du Pisani (2001: 158) calls the puritan nature of Afrikaner hegemonic masculinity. He does not adhere to the principles of "rigid austerity and strictness in conduct and morals" with which this type of hegemonic masculinity is more usually associated. Yet, despite this outward maintenance of a strict code of conduct, it is also true that there were frequent sexual encounters across the marital and racial boundaries imposed by the state. A relevant case in point is Willem's sexual escapades with Antje (in the attic of the outhouse, then in the tavern section in the front part of the homestead, the attic above the main bedroom, in the bed itself (41-43)). One way of justifying the sexual antics was to rely on the so-called ideology of paternalism that formed an integral part of Cape society. Giliomee (2003: 49) explains this paternalism as follows: “Owners propagated the myth that slaves were members of the household and even part of the extended family, consisting of the patriarch's immediate family, some brothers and sisters and their families, one or more bywoner families, [and] Khoikhoi servants and slaves."

Another interesting facet of Afrikaner masculinity evident in the novel is the misuse of the Bible, as well as the superstition of women (42). This is particularly ironic since the stereotypical portrait of the colonial Afrikaner is that of a staunch 
Christian and guardian of moral values. When Willem Mostert's wife confronts him about his conduct with the female slaves, he describes his behaviour as "the Cape custom" (42) based on the Old Testament. He uses her beliefs in witches and superstition to "reduce his wretched wife (...) to a permanent state of abject terror" (42). ${ }^{6}$

Antje's death and Willem Mostert's role in it signify the beginning historically of a long history of exploitation of women, in particular black women, in the Southern African context. Willem Mostert's suicide by hanging is an attempt to seek penance for his deeds. His burial of Antje's body under the floor of his house is an attempt to restore their previous relationship within the boundaries of the house. Antje' burial ground also signifies that the remains of abused women will always lurk in the historical psyche of the Afrikaner male. Ruben, as heir to this historical past, will have to find her a place of rest. This also explains his attempts to support Magrieta Daniels, the descendant of Antje of Bengal.

In this novel, Ruben Olivier, a 65-year-old retired librarian, represents the modern, urban Afrikaner and within the symbolic space of the house in Papenboom Road he continues the historical line started by Willem Mostert. An analysis of his character suggests that Brink's portrayal of him deconstructs some of the notions associated with Afrikaner hegemonic masculinity.

According to Morrell (2001: 127) one of the central and critical issues in the study of masculinity is the issue of fatherhood and the role men play as fathers. It is within the home that the men as fathers, "reflectively and reflexively act out their masculinity." It is also within the context of the family that the father's position of power is "contested and challenged and therefore has constantly to be defended and reasserted." Ruben's own father confirms several of the Afrikaners' traditional ideas concerning fatherhood and masculinity. Ruben's childhood has been one of belonging to "the hard, masculine world of the farm" (29) where only the Bible was read and where his only escape from reality was through books and libraries ("a place of ultimate refuge", 32). His father-in-law also presents the traditional ideal of the hard working farmer, affluent and proud of his tradition and lineage ("the pride of seven generations of Hugo's", 4). In contrast, Ruben is seen as someone with "hardly a penny to his name and only the smell of books around him" (4). Life on the farm centred on the Bible and the concomitant Calvinist principles and interpretations of the Bible, coupled with a strong work ethic. The only escape from that reality for Ruben was through books and libraries. His only real companion on the farm was Outa Hans, who "could tell stories about the rain" (29). As an outsider child on the farm the only true companion for the young boy is the farm worker or the Other. This is later echoed in Ruben's relationship with Johnny MacFarlane, who is also Othered by society because of his alleged homosexuality.

However Ruben reveals to Tessa that in his relationship with his father there was "always something ambiguous" (83) and that his father understood him much better 
than Ruben wanted to believe. It is clear from the narrative that his father "was never meant to be a farmer" (82), but since he was the only son and heir, he had no choice in the matter. His father, just like Ruben, is described as having been "[a]n introverted child" (82) who wanted to become a teacher: "He would recognise in me the child he himself had once been - a studious boy, a dreamer, driven by an ambition to explore the secret world beyond the confining realities of the Old Testament" (84). The imposition of a specific patriarchal identity onto his own father by his grandfather, aptly named after the Biblical giant, Goliath, suggests that Ruben's father was in fact silenced by tradition and the demands of hegemonic masculinity. Stoffel had to marry and produce an heir and subscribe to his father's belief "that women served only one function in the world" (83), namely to bear children.

The ambiguity of the relationship between Ruben and his father is evident from the following passage, particularly since it shows that his father had lived out his dream through his son:

My own future had been decided from that first day when Pa had forgotten me in the town library. And he supported me, though he hardly ever spoke about it directly. When it was time for me to go to university, he took me to the bank and made me sign some papers already drawn up. Only then did I discover that over the years he'd saved the money to make this possible. It was all signed over to me: a convoluted process, as I was still a minor and a sympathetic teacher had to be found to act as a shield (85).

Ruben's university studies coincided with his father's loss of the farm because of debt, which suggests that the father could now leave the harsh world of the farm behind and live out his dream through his son. His father's life, "wasted by disappointment and depression" (85), ended in suicide and prevented them from reaching out to one another. The feelings of guilt Ruben shows after his failure to show compassion towards Johnny are possible projections of his guilt for letting down his father, although both are a result of his self-centredness.

According to Gallipeaux (2001) Ruben is portrayed as "an unfaithful husband and a cold, aloof father", especially since Ruben himself acknowledges that "[t]here has always been a distance between [his] sons and [himself], for which [he's] willing to take the blame" (260). But the murder of his neighbour, Johnny MacFarlane, has even had an effect on the relationship between Ruben and his sons. One of the main reasons why his son, Johann, lives in Australia is the escalating crime rate in the new South Africa, and "the way hospital services are going down the drain" (25). Louis, a civil engineer, lives in Canada because it is financially more profitable and crime is less present. Both are white, educated men who feel that they do not belong in the new South Africa and base their decisions to emigrate on the loss of "standards" or privileges typical of the old, white-controlled South Africa. 
The interaction between Ruben and his children is a clear example of what Morrell (2001: 127) describes as the contesting and challenging of authority. Both sons believe that their father, after his angina attack, needs to spend the rest of his days in peace (4) and want him to give up his house, the seat of his patriarchal authority. A new masculinist discourse signifies the change in position and authority. The sons are independent, married and live their own lives and feel obliged to interfere in their father's life. Cathy, Johann's wife, manages to persuade Ruben to place an advertisement for a lodger. By sending her as emissary, his sons know that they would convince their father, especially since he is so susceptible to female charm - as will be evident in his relation with Tessa.

By studying the affair between Ruben and Tessa Butler, the reader learns a lot more about other facets of the older man's masculinity. The relation between the young woman and an older man, twice her age, provides us with insights into the Afrikaner male's views on sexuality. The relation that Ruben has with Tessa echoes the earlier incident with the young Lenie, when he, as a young boy felt the need to protect her against his brothers (28). In the present he feels the need to protect Tessa from her suitors, and in an act of jealous rage, he even punctures one of her suitors' car tyres (131). ${ }^{7}$

This preoccupation with women and in particular the urge to fight for her rightful position in a patriarchal society is an attempt by the author to inscribe his familiar characterization of women as nymph-like whores in a new feminist discourse. Yet one remains sceptical, especially since it is constantly undermined by the narratorfocaliser's vulvacentric obsessions and his excessive preoccupation with Tessa's sexiness and sexual exploits. Stephen Whitehead (2001: 356-357) is of the opinion that in the case of a pro-feminist attitude among men, it is often a case of trying to find "more strategic responses to their perceived loss of gendered power". The emphasis is merely on "maintaining [of] location within the social and cultural parameters which define and confirm its gendered status". Brink's attempt to write from a more sympathetic male perspective about women and women's rights does not prevent him from still inscribing in his discourse the waif-like stereotypical female character associated with his oeuvre. ${ }^{8}$ Despite creating a new type of male, he undermines his own discursive project when he retains his overtly voyeuristic perspective on the female body.

The first encounter between Ruben and Tessa occurs when he listens to her voice on the phone and deduces from the voice that she has "[a]n unusual voice, with a kind of liquid darkness in it, and hidden laughter, reminding [him] somewhat of Françoise Hardy in the sixties" (7). He immediately associates her with the young French songstress in the sixties known for her love ballades, her long hair and childlike beauty. When she arrives at his house for the interview this romanticized recollection underpins his description:

Was it really only on Saturday, the night before last, that she arrived with dirty feet and a smudge on her cheek, an hour late? Her black hair, hacked off unevenly and 
very short, was plastered wetly against her small neat skull. She was wearing a large shapeless sweater that sagged down to her bare knees and massive clodhopper boots (16).

The emphasis is not so much on her sexual attraction as it is on her natural beauty and her unspoilt natural looks. Later on he mentions that having her in the house is as if she "had always been there, a child of the home" (21) which suggests that she takes the place of his daughter who died at childbirth. But the emphasis on her child-like state is definitely an attempt by the older man to turn her into an object of desire, probably a sexual object ("a nymphet") to satisfy his desires. She asks him about the ways in which he finds sexual satisfaction and from his "Note on sex for the aged widower" (22) we learn more about the sexual needs and desires of such an older heterosexual Afrikaner man. His only form of consolation comes from phoning an escort agency (22) and having anonymous sexual encounters with women he does not know. From his interaction with Tessa it is evident that she is sexually more experienced and enlightened than he is, while her use of "fuck" in reference to sexual intercourse indicates her membership of a younger generation. As a result, Ruben starts to feel "a tingling in [his] loins" (27) and this is reinforced when Tessa asks to go to the bathroom. In floral and poetic language ("Ah sweet bird of youth", 39) Ruben expresses his delight when he can hear her urinate (he uses the word "pee" to describe it, probably to be as open-minded as she is with her use of four-letter words). ${ }^{9}$ He experiences delight when he becomes aware of the bodily functions of the female subject and it arouses him even more. An excellent example of his growing awareness of her body and his voyeuristic gaze thereupon is illustrated in the following paragraph: "She looked hard at me, then came past me to the couch and flopped down on it, swinging up her legs with a charmingly casual flash of the small white triangle of panties between her thighs, the sort of thing which the sex-starved hermit I'd become cannot fail to notice" (39).

The above paragraph illustrates clearly what Jeremy Hawthorn (1994: 82) pinpoints as the essence of the so-called male gaze: the gaze is in the possession of the male (Ruben) and by focusing on Tessa's "white triangle of panties" and not on her as a person, she is deprived of power and of her subjectivity. She becomes an object of desire, someone to be viewed. As soon as she moves into his house, Ruben begins this seduction game and has to acknowledge that "[he was] behaving like a twenty-yearold" (73). Whereas before he regarded himself as some sex-starved recluse, now he shows visible signs of his desire when he wakes up "with a more powerful morning hard-on that [he'd] had in years" (93). He even compares his preparation for sexual intercourse with her in terms of a conquest: "The little packet [of condoms] lives in my sock drawer. I feel like a freedom fighter keeping sticks of dynamite in his room" (100). Does the choice of this metaphor suggest a violent way of asserting his mascu- 
linity? Is Tessa some virgin territory that needs to be conquered and colonized? However, it underscores Ruben's pathetic attempt at making an impression on Tessa and conquering her sexually, especially when one reads about him trying on a condom. ${ }^{10}$ When he does manage to have sexual intercourse with her, his vulvacentric obsession is reiterated. In language befitting a pornographic catalogue he has to point out that "[s]he'd shaved her mound" (113), that there is an "exquisite vulnerability to the exposed sex" and later on, that she should allow him "to kiss her pussy" (116). The female other is reduced to a mere sex object and there is a preoccupation confined to her genital sexuality, which according to Segal (2001: 106) suggests that most "men's fantasies, desires, and experience of sex in actual relationships with women [recall] pre-pubescent fantasies." Ruben does ask Tessa whether her decision "[to] shave [her] pussy" (192) is an expression of "a way of wishing [she was] still a little girl" (192), but according to her it should be seen as a way of getting in touch with her body. Interestingly enough, he immediately reduces this "being in touch with one's body" to suggest a highly eroticised sense of being.

A central passage in the novel that inevitably calls for comparison with Coetzee's Disgrace, ${ }^{11}$ and which comments on the interaction between Ruben and Tessa, is the incident with the attackers (292-296). Earlier in the novel Tessa remarks that, "[t]hey say one out of every two women in the country will be raped in her lifetime" (25). Tessa, as the modern descendant of Antje of Bengal, manages to save both her and Ruben's lives by screaming ("I'd never thought that such sound could come from her", 295). In a grotesquely politically incorrect manner, the reader is somewhat prepared for the incident with the attackers when Ruben mentions that Tessa was not wearing her bra during their walk in Newlands forest. This is done not to describe his desire, but "because [the details] are relevant for what followed" (292). The narrator supports the sexist assumption that women who dress provocatively want to be raped, which inevitably forces the reader to ask the question: Is Ruben really a profeminist? Is he really a liberated male who champions the rights of women or is he merely portrayed as just another heterosexual male who supports stereotypical notions about women and their sexuality? In his case there appears to be no "desire to break free from existing stereotypes about the Afrikaner" (Du Pisani, 2001: 171). Does Brink imagine he is portraying a new kind of male, while inadvertently revealing how habituated to male sexist perceptions of women he remains?

As is the case with David Lurie in Disgrace, Ruben is also powerless to do anything during the attack and he even feels that "[he] should have brought a cane" (294). It is perhaps a less violent weapon than a gun, but it still signifies his impotence during the situation, and his reversion to the notion of the powerful, protective (and whenever necessary, fiercely violent) male. Yet, the older white male with his cane is unable to defend himself and his beloved against the young black males armed with flick knives (293). The choice of weapon suggests something of their phallic masculinity: 
the older man with the useless cane and the younger men with the dangerous and fast-moving knives. Ruben, as representative of the old white hegemonic order, is associated with a cane, a remnant of the colonial times when one could freely go for a walk in the woods, whereas the young men are associated with fast-moving knives. The cane would also have been an instrument of authority making reversion to physical power unnecessary. The latter suggests that they are contesting the existing order and replacing it with what Xaba (2001: 112) calls "masculinities of survival". In the new South Africa where white men such as Ruben are still economically stronger than the rest of the population, the young black men find that the "masculine characteristics they possessed were inappropriate for the new South Africa". As a result, they resort to "finding affirmation and confirmation from each other" (Xaba 2001: 112). The only alternative for them as economic, political and social outsiders is to form groups who attack affluent people and steal from them. The setting for the confrontation between Ruben, Tessa and the attackers is also significant in the sense that the characters return to the forest, the primal seat of violent encounters where all behaviour is reduced to animalistic fighting as part of some type of pecking order.

During the attack and the near-rape of Tessa by the young men, she is the one who saves their lives with her screams, described as ominous and eerie sounds, which Ruben could not believe could emerge from her body. The scream is a scream against all men: against men who attack defenceless women like herself and women like Antje or Magrieta. It is also a scream to end the silencing of women - women like Lucy Lurie who accepted her ordeal in silence. It is significant that Ruben " [touches] his throat" (296) after the ordeal, since he was now the silenced one; the Afrikaner male who is unable to protect his beloved against the violence of other men. ${ }^{12}$

In the final chapter of the novel we find an interesting exploration of the so-called "rights of desire" (rites of desire?) when Tessa forces herself onto Ruben and exclaims: "Fuck me! ... Fuck me, damn you!" (303). This final encounter between the two of them reads like a controlled enactment of the rape scene that could have taken place in the forest. Tessa is portrayed as "possessed by an uncontrollable violence" (303) whereas Ruben acts in an endearing and supportive manner. Now that he has the opportunity to succumb to the "act of taking" (303) and to satisfy his lust for her, he comes to the realization that his thwarted possessiveness was indeed a futile endeavour ("Is this what I envied others for [?]", 303). It is important to note that there is a progression in her plea, because at first she asks him "to help [her]", then "[to] make love to [her]" and finally to "[f]uck [her]". Ruben is definitely not unaffected by her sexual demands, because even though he is portrayed as the supportive male, reference is made to his "rampant [penis]" (303). ${ }^{13}$ What we detect here is the stereotypical notion that men have no control over their own genital sexuality. Another commonly held notion about male sexuality is the notion that men regard "a feeling of rejection as debilitating" (McCloughry 1992: 168). In the case of Ruben, it is the man rejecting 
the woman, refusing to be opportunistic. His rejection of Tessa not only emphasizes his dominant position in the relationship between the two of them, but also conveys the idea that the female Other is reduced to "some dumb kind of animal" (a description also used to describe the male phallus) in times of crisis, indicating that the woman needs a strong, supportive male to help her cope with the situation. The impression is created that in times of distress her only reward to express her gratitude is to give herself sexually to the man in her life.

In the end Tessa's decision to leave and "free [Ruben from her]" (304), especially since she has "ruined [his] world" (305), signposts the true ideological message regarding masculinity: although her presence was like "[a] miracle of rain after three years of [sexual and intimate] drought" (305) he can continue unperturbedly with his life. He is filled with hope, knowing that there is "the world outside" (306) of which he feels part. His "desire is [also] intact" which inevitably takes the reader back to the "notes on desire" (154) earlier on in the novel. As a "redundant" older white male he still feels that he has "the right to live, to move, to breathe" (154, original emphasis). His remarks that the "possibility of fulfilment" and "fulfilment [as] the end of desire" are also apposite in this context. He did not get the fulfilment of his desire with his beloved object of desire, the younger woman with her "adolescent naïveté, her arrogance, her bitchiness [and] her untouchability" (151). He is still the self-centred, aloof man, who "never felt much need of other people" (8) and who will continue to live his life, "only with the smell of books around him" (4). Yes, Ruben is willing to adapt to the new South Africa, but one may remain sceptical whether he would really be able to re-enter that world. He refers to the fact that what "has to be faced" (306) is something that "all [his] life [he has] tried to turn away from" (306) and that is, "the world outside" (306). His reference to his "desire [that] is intact" (306) does, however, leave us with a sense of scepticism at the close of the novel. It leaves us with the feeling that once every now and then a younger woman might come along to liven up his existence, but should the need arise for sexual gratification, he will make a "late-night call" to "an agency listed in the smalls" (22) and feed his "infuriating flesh" (23) within the walls of his own, safe home.

\section{Notes}

1. Compare the observation of Morrell (2001: 18) that until recently South Africa was "a man's country" and the uneven distribution of power "gave [white men] privileges but also made them defensive about challenges (by women, blacks, and/or other men)."

2. The article is based on a chapter in Crous (2005) completed under the supervision of Prof. A.H. Gagiano, Department of English, University of Stellenbosch. The title derives from The Rights of Desire (Brink 2000: 22) and page references refer to this edition.

3. Sue Kossew (1996: 29) in a comparison of the writing of J.M. Coetzee and Brink observes that in the case of the latter there is a "reaction to traditional values of Afrikaner nationalism on both political and personal levels," as well as an attempt to "[sever] himself from the conservative moral traditions of Afrikanerdom." 
4. A fascinating aspect of Ruben's character is his Oedipal relation with Magrieta Daniels, his housekeeper. Louise Viljoen (2002: 109), following Anne McClintock, points out that the nanny has played an important role in the lives of children and although Magrieta was not Ruben's nanny, through her associations with Antje of Bengal there are several Oedipal resonances in their interaction - and also her interference in his love life could be interpreted against this background. Jeff Gallipeaux (2001) regards the portrayal of the interaction between Ruben and Magrieta as "[t]he most successful subplot in [the novel]", especially since he finds the depiction of Antje's narrative as sentimental and superficial. I take issue with this since the inclusion of the narrative of Antje of Bengal is an attempt to sustain the historical perspective on women's oppression, starting with Antje and concluding with Magrieta. Ruben indeed has an interesting relationship with Magrieta. Not only is she the housekeeper, but she acts as his confidante, his conscience and she keeps him informed about life outside the white suburbs. Her presence in his life is significant as she shows the reader another facet of history in South Africa, namely the effects of forced removals (141).

5. "Sy huis dra die herinneringe van die geskiedenis van die land se mense, die land waarin hy moet oorleef, maar die hede en die toekoms, gebeur ook in en om dié huis." For a related discussion on the depiction of "the house in fiction" (particularly in two J.M. Coetzee novels), see Heyns (1999: 20-35).

6. One example of the deconstruction of the image of the religious pioneer occurs when Willem, "still firmly ensconced between Antje's thighs", "would make the sign of the cross over Susara's head" (46). Not only does it link miscegenation, sexual exploitation and blasphemy, but the gesture shows his disdain for religious institutions.

7. It is telling that a wealthy and privileged white man can here, in another type of jealous manifestation (than that of the black youths who rob and murder and rape well-off whites) engage in knife-wielding crime and get away with it.

8. Compare J.C. Kannemeyer's (1983: 384) remark that Brink's sexual scenes are often sentimental and syrupy and adolescent at times. Regarding his female heroines, Anita Lindenberg (1998: 305) writes as follows: "The lover is the typical Brink projection at its most feeble: she is half girl, half slut, undeterred and vitalistic with a sense of mystery - often more of a delusion than the truth" ["Die minnares is die tipiese Brink-projeksie op sy saaiste: half dogtertjie, half slet, argeloos en vitalisties, met 'n geheimsinnigheid wat meer na delusie as na die waarheid lyk."], my translation). Tessa's obsession with losing her virginity (163) is a recurring theme in Brink's novels, thus suggesting that women need to be sexually initiated by men, as some rite of passage.

9. Another curious incident in the text where urination is also used as a form of interaction between the sexes, occurs during an incident in Ruben's youth when a girl at school would choose a particular boy to "pee on her feet" (209) to warm them and as an expression of "truest love". It is seen as some form of worship by Ruben, probably as a remnant of some pagan belief in his subconscious.

10. Not to mention the excruciatingly sentimental way of describing the condom as "the corpse of a saint" floating on the surface of the toilet basin!

11. Michael Wood (2001) described Brink's novel as "an analogue and answer to that austere and brilliant novel" (Coetzee's). There is indeed an intertextual relation between the two novels, since Brink's novel takes its title from a remark in Coetzee's novel, quoted as one of the epigraphs of Brink's text.

12. In contrast to Disgrace where the dogs are also killed during the attack, in this case "there was a sound of dogs barking" (296) which suggests that help was on its way and the situation was not as bleak and as futile as was the case with the characters in Disgrace. From this we deduce that for Brink there is indeed a space for the white male in the new South Africa but he has, in the words of Gayatri Spivak (1996: 4), to "unlearn his privilege as his loss". He has to realise when to relinquish power and especially to accept his position as the silenced one. Reuben does not share David Lurie's vision of the white male being similar to a destitute dog waiting to be put down. What keeps him going is the realisation that there is a world outside, which "requires [him] and strangely concerns [him]." The constant yearning for the woman of his desires keeps him going, because in the end he realises: "[His] desire is intact" (306).

13. Lynne Segal (2001: 107) quotes Nancy Friday whose survey shows that "men strongly desire to be caregivers just as much as women." A poignant example of this occurs when Ruben accompanies Tessa to the abortion clinic (171). The age gap between the two is emphasized in the scene when Tessa is mistaken for his daughter. The scene calls to mind Riana's loss of their baby girl (183), the incident with Antje's miscarriage (44) and Magrieta's "stillborn child" (88). This highlights the notion of barrenness and sterility among women through the ages, often caused through male indifference. 


\section{Bibliography}

Adams, Rachel \& David Savran. 2002. The Masculinity Studies Reader. Oxford: Blackwell.

Brink, André. 2000. The Rights of Desire. London: Secker \& Warburg.

Boylan, Roger. 2001. The Rights of Desire. Boston Review (Summer).

Coetzee, J.M. 1999. Disgrace. London: Secker \& Warburg.

Connell, R.W. 1995. Masculinities. Cambridge. Polity Press.

Crous, M.L. 2005. Presentations of masculinity in a selection of post-apartheid male-authored novels. Unpublished MA thesis. Stellenbosch: University of Stellenbosch.

Du Pisani, Kobus. 2001. Puritanism Transformed: Afrikaner Masculinities in the Apartheid and PostApartheid Period. In Robert Morrell (ed.). Changing Men in Southern Africa. Pietermaritzburg: University of Natal Press, 157-176.

Du Plooy, Heilna. 2002. Die huis as domein: ' $n$ Ganse lewe in ' $n$ intieme ruimte. Stilet XIV (2): 38-52.

Epstein, D. 1998. Marked Men: Whiteness and Masculinity. Agenda 37: 49-59.

Gallipeaux, Jeff. 2001. From South Africa's Tortured Past, a Muddled Present. San Francisco Chronicle, 1 April. <www.sfgate.com/cgi-in/article.cgi? file=/chronicle/archive/2001/04/01/RV1027>

Gilliomee, Hermann. 2003. The Afrikaners. Biography of a People. Cape Town: Tafelberg Publishers.

Hawthorn, Jeremy. 1994. A Concise Glossary of Contemporary Literary Theory. London: Edward Arnold.

Heyns, Michiel. 1999. Houseless Poverty in the House of Fiction: Vagrancy and Genre in Two Novels by J.M. Coetzee. Current Writing 11 (1): 20-35.

Kannemeyer, J.C. 1983. Geskiedenis van die Afrikaanse Literatuur 2. Kaapstad: Academica.

Kossew, Sue. 1996. Pen and Power: A Post-Colonial Reading of J.M. Coetzee and André Brink. Amsterdam: Rodopi.

Lindenberg, Anita \& Beukes Marthinus 1998. André P. Brink (1935-). In H.P. van Coller (red). Perspektief en profiel 1. Pretoria: Van Schaik, 294-329.

McCloughry, Roy. 1992. Men and Masculinity. London: Hodder \& Stoughton.

Morrell, Robert (ed.) 2001. Changing Men in Southern Africa. Pietermaritzburg: University of Natal Press.

Posel, Deborah. 2005. "Baby rape": Unmasking secrets of sexual violence in post-apartheid South Africa. In Graeme Reid and Liz Walker (eds.). Men Behaving Differently. South African Men since 1994. Cape Town: Double Storey, 21-64.

Ross, Robert. 1993. Beyond the Pale - Essays on the History of Colonial South Africa. Johannesburg: Wits University Press.

Samuelson, Meg. 2002. The Rainbow Womb: Rape and Race in South African Fiction of the Transition. Kunapipi 24 (12): 88-100.

Schroeder, Heather Lee. 2004. Haunted longing in South Africa: Brink's latest weaves together ghosts, romance. The Capital Times (4 June).

Segal, Lynne. 2001. The Belly of the Beast: Sex as Male Domination? In Stephen Whitehead \& Frank J. Barrett (eds.). The Masculinities Reader. Cambridge: Polity Press, 100-112.

Spivak, Gayatri. 1996. The Spivak Reader. New York: Routledge.

Swart, Sandra. 2001. Man, Gun and Horse: Hard Right Afrikaner Masculine Identity in Post-Apartheid South Africa. In Robert Morrell (ed.). Changing Men in Southern Africa. Pietermaritzburg: University of Natal Press, 75-90.

Van Coller, H.P. 2002. Eenders en Anders: Die Diskursiewe Netwerk in Donkermaan van André P. Brink. Stilet 14 (1): 50-71.

Viljoen, Louise. 2002. Kan die slaaf praat? Die stem van die slaaf in enkele Brink-romans. Stilet XV (2): 92-116.

Visagie, Andries. 2001. Fathers, sons and the political in contemporary Afrikaans fiction. Stilet XIII (2): 140-157.

Whitehead, Stephen \& Barrett, Frank J. 2001. The Masculinities Reader. Cambridge: Polity Press.

Wood, Michael. 2001. Chains of Love. The New York Times, 17 June. <www.nytimes.com/books/01/06/17/ reviews/010617.17woodlt.html>

Xaba, Thokozani. 2001. Masculinity and its Malcontents: The Confrontation between "Struggle Masculinity" and "Post-Struggle Masculinity" (1990-1997). In Robert Morrell (ed.). Changing Men in Southern Africa. Pietermaritzburg: University of Natal Press, 105-124. 